\title{
Law Clerks in Judges' Eyes: Tradition and Innovation in the Use of Legal Staff by American Judges*
}

\author{
John Bilyeu Oakley† \\ Robert S. Thompson $\$$
}

Plagued by the burden of bloated caseloads and constrained by the inortal capacities of judges, nnodern judicial decisionmaking proceeds in all courts of national significance only by the delegation to law clerks of much of the labor of judging. Long considered too confidential for public discussion, the relationship between judges and law clerks has becoine the subject of probing academic inquiry im the last twenty years. ${ }^{1}$ The new literature on law clerks confirms their indispensability;

* This Article is an abridgement of portions of the authors' forthcoming book, LAW Clerks AND the Judicial Process, to be published in 1980 by the University of California Press. The authors gratefully acknowledge the permission of the University of California Press to publish this abridgement. We leave to the book itself our acknowledgements of the many persons who have assisted us im this study. Having edited this version of our work so as to engage but not to fatigue the casual reader, we also reserve to the book our comprehensive presentation of supporting information and documentation. Those readers with continuing imterest in the topics broached here will find in the full-length account of our research additional details on the previous literature about law clerks, our research methods, the form and content of our data, and the operating procedures of the courts we studied.

$\dagger$ Professor of Law, University of Califorma at Davis Sclıool of Law. Currently on leave as scliolar-in-residence at the Civil Rights Division of the United States Department of Justice. B.A. 1969, University of California at Berkeley; J.D. 1972, Yale Law School. Professor Oakley served as a law clerk to Chief Justice Donald Wright of the California Supreme Court, and to Judge M. Joseph Blumenfeld, United States District Court for the District of Connecticut.

$\$$ Professor of Law, University of Southern California Law Center. B.S. 1940, L.L.B. 1942, University of Southern California. Forner Associate Justice of the California Court of Appeal for the Second Appellate District.

1. See, e.g., R. Leflar, Internal Operating Procedures of Appellate Courts 79-94 (1976); D. Meador, Appellate Courts: STaff and Process in the Crusis of Volume (1974); National Center for State Courts, The California Courts of Appeal 71-118 (1974) [hereinafter cited as CAL. Courts of APPEAL]; M. SCHICK, LEARned HaNd's Court 98-99, 106108 (1970); J. Wilkinson, Serving Justice: A Supreme Court Clerk's View (1974); Baier, The Law Clerks: Profile of an Institution, 26 VAND. L. REv. 1125 (1973); Carrington, Report on Group Discussions, Topic II: Responsibility for Decisions, in 5 ADVISORY COUNCIL FOR APPELlate Justice, Appellate Justice: 1975-Supplement, Proceedings And Conclusions 65-67 (P. Carrington ed. 1975) (National Conference on Appellate Justice, Jan. 23-26, 1975); Dorsen, Law Clerks in Appellate Courts in the United States, 26 Mod. L. Rev. 265 (1963); Fite, Potts, \& Sweeney, Law Clerkships: Three Inside Views, 33 ALA. LAw. 156 (1972) (discusses state and federal courts in Alabama); Francis, Post-Argument Procedures, 52 F.R.D. 51, 70, $71-73$ (1971) (dis- 
law clerks have become fixtures of American legal culture.

This study examines the use of law clerks by a spectrum of state and federal judges. It focuses on the impact that two intersecting trends in the use of law clerks have had on the quality of judicial decisions. The first trend features increased reliance on law clerks as a means of accelerating adjudication. The second features decreased concern over traditional criteria for the qualifications, personality, and tenure of law clerks. We present the results of interviews with sixtythree state and federal judges on how they and their courts are accommodating these trends, and we offer conclusions on how judges can continue to enjoy the traditional benefits of law clerks without sacrificing the increased productivity demanded by the "crisis of volume."2

\section{INTRODUCTION}

Over the past century American judges have come to rely, to varying degrees, on the "traditional" law clerk, a recent law school graduate whose arrival at the court brings from academia a fresh approach to recurrent legal problems. Possessed of superior intellect and exceptional writing ability, the traditional clerk works at the side of a single judge for one or two years. Judges have prized the idealism, aggressiveness, and imitiative of the traditional clerk. It is through discussions with their clerks that judges sharpen their own views of a case; law clerks nust be brash as well as bright if their sounding board is to provide more than an echo. Often isolated from their former colleagues at the bar by elevation to the bench and from their judicial fellows by the press of business, judges also welcome the warm personal relationships that develop with their talented legal assistants-relationships that are enhanced by the sense that the traditional law clerk is as much the apprentice of a master lawyer as the subordinate of a busy judge.

Many judges and cominentators have become convinced, however, that courts are not always best served by the traditional law clerk who cones to the court better versed in the theory than the practice of law. Some reforners argue that courts will be better served by the well-

cusses New Jersey Supreme Court); Goldberg, Preparation for Hearing Oral Argument, 63 F.R.D. 499, 500-04, 506 (1974) (discusses United States Court of Appeals for the Fifth Circuit); Lesinski, Judicial Research Assistants: The Michigan Experience, 10 TrLal Judges' J. 54 (1971); Medina, Some Refections on the Judicial Function at the Appellate Level, 1961 WASH. U.L.Q. 148 (discusses United States Court of Appeals for the Second Circuit); Newland, Personal Assistants to Supreme Court Justices: The Law Clerks, 40 OR. L. Rev. 299 (1961); Williams, Justices Run 'Nine Little Law Firms' at Supreme Court, SMITHSONIAN, Feb. 1977, at 84; Wright, Observations of an Appellate Judge: The Use of Law Clerks, 26 VAND. L. Rev. 1179 (1973).

2. D. MEADOR, supra note 1. 
tramed professional who makes clerking a career. ${ }^{3}$ Others contend that there is a low limit to the number of traditional law clerks whom any one judge usefully can employ. Their cure for appellate court congestion is the "central staff"-a corps of lawyers who work for the court as a corporate whole. ${ }^{4}$

California's supreme court and courts of appeal have enthusiastically adopted each of these innovations-the "career" clerk and the "central staff." Indeed, the use of career clerks and central staff has become so widespread that we fear for the contmued existence of the traditional law clerk in the California appellate system. We decided to explore the implications of this trend for the quality and quantity of the work that California appellate courts are producing. We sought to test our strong personal preferences for the traditional law clerk agaimst the perceptions of as many judges who use law clerks as we possibly could interview.

This study presents data from interviews with sixty-three judges of federal and state courts im California on their personal use of law clerks, and on the use of law clerks by their courts as a whole. We focus on these judges' beliefs regarding the proper function of law clerks, and their perceptions of the relative merits of traditional law clerks and the new breed of indefinitely tenured career clerks. We also explore their opinions regarding whether law clerks are better employed by individual judges or collectively in a central staff. In view of California's large and respected state court system, its many federal courts, and the heterogeneous population which both systems serve, we think our study has relevance to current or coming patterns of law clerk usage in all American courts.

We found that traditional patterns of law clerk usage are more firmly entrenched in the federal courts than in the state appellate courts. There is a profound difference in the philosophy of the two systems' approaches to the cominon problem of oppressive caseloads. All the courts vary with respect to the type and pace of decisions required of their judges, the prestige they offer to their short-term law clerks, and the salaries they offer to their career clerks. These variations have led the California appellate courts to make efficiency the prime criterion in organizing their use of law clerks. These courts thus

3. See B. Witkin, Manual on Appellate Court Opinions 12-14 (1977); O'Connell, Streamlining Appellate Procedures, 56 JuD. 234, 236 (1973). See generally Thompson, Mitigating the Damage: One Judge and No Judge Appellate Decisions, 50 CaL. ST. B.J. 476, $513-15$ (1975).

4. See P. Carrington, D. Meador, \& M. Rosenderg, Justice on Appeal 44-48 (1976) [hereinafter cited as JUSTICE ON APPEAL]; Lesinski \& Stockmeyer, Prehearing Research and Screening in the Michigan Court of Appeals: One Court's Method for Increasing Judicial Productiv. ity, 26 VAND. L. Rev. 1211 (1973). See generally Cameron, The Central Staff: A New Solution to an Old Problem, 23 U.C.L.A. L. Rev. 465 (1976). 
embrace career clerks as welcome antidotes to the crisis of volume, tolerating any loss in quality in the process as justified by the greater perceived efficiency of career clerks. The California model of law clerk use accepts delegation of soine cases for disposition almost entirely by staff subject only to general judicial supervision. The federal courts emphasize the contribution of traditional law clerks to the quality of their decisions, and try to preserve a role for such clerks even in central staff systems. The federal model is more restrained in its willingness to delegate de facto substantive decisionmaking to its legal staff, striving to limit staff authority to such processing of cases as enhances and facilitates speedy judicial decisions while still leaving the judges soinething to decide.

II

\section{The History of the Use of LaW Clerks}

Horace Gray, as Chief Justice of the Massachusetts Supreme Judicial Court, seems to have been the first American judge to use law clerks. ${ }^{5}$ In the summer of 1875 , Gray began his practice of procuring the services of a highly ranked new graduate of the Harvard Law School ${ }^{6}$ at his own expense. Each year a new clerk would arrive from the halls of Harvard, referred to the Chief Justice by his emment half brother, Professor John Chipman Gray. ${ }^{7}$ When Horace Gray was appointed to the United States Supreme Court in 1882, he brought the use of law clerks to the nation's highest court.

Samuel Williston's clerkship with Justice Gray illummates its origmator's conception of the law clerk institution. ${ }^{8}$ Williston served his judge as a sounding board and editor. He was expected to review all of the newly filed cases and to formulate a recommended position. ${ }^{9}$ Gray, at his best in oral colloquy, treated the law clerk nuch as a law professor would treat a student, exploring the clerk's views and only imphicitly revealing his own. Gray expected his clerks to bring the latest theories brewing at Harvard to bear on the Court's problems. Williston was frequently asked to draft opinions in cases assigned to Justice Gray, but these drafts purportedly served only as discussion pieces to enkighten Justice Gray's own opinion writing. ${ }^{10}$ In addition, Williston

5. See Fredonia Broadcasting Corp. v. RCA Corp., 569 F.2d 251, 255 (5th Cir. 1978); Baier, supra note 1, at 1132 .

6. Williston, Horace Gray, in 8 GREAT AMERICAN LAWYERS 157-58 (W. Lewis ed. 1909) [hereinafter cited as Gray].

7. S. Williston, LIFE AND LAW 87 (1940); Gray, supra note 6, at 158.

8. S. WiLliston, supra note 7; Gray, supra note 6.

9. See Gray, supra note 6, at 158-59.

10. S. Williston, supra note 7, at 92; Gray, supra note 6, at 159. 
read and commented on opinions circulated by other Justices. ${ }^{11}$

A scholar of note, Gray was able to hold his own intellectually with his clerks. He could sift through their ideas and adopt what he found useful without becommg dependent. ${ }^{12}$ Childless and a bachelor for the greater part of his judicial career, Gray had a parental affection for his clerks. He took interest in their progress during the year with him and throughout the rest of their hives. ${ }^{13}$

Gray's method of using law clerks was not emulated by his colleagues even after Congress assumed the cost in $1886 .{ }^{14}$ Although nine Justices were employing assistants by 1888 , the typical Justice sought to retain his clerk for as long as the salary level would permit. ${ }^{15}$ Gray's clerkship practices survived, however. Justice Gray was succeeded on the Supreme Court by Oliver Wendell Holmes, Jr.-another former Chief Justice of the Massachusetts Supreme Court-who, within three years of assuming his post in Washington, began to choose honors graduates of the Harvard Law School annually to serve as his clerks. ${ }^{16}$

In 1919, Congress authorized each Justice of the Supreme Court to employ a "law clerk" and a "stenographic clerk."17 It became the custom of the Court over the next twenty years for each Justice to have one law clerk in the fashion of Horace Gray, and a clerical assistant. ${ }^{18}$

11. S. WILListon, supra note 7, at 92 .

12. See Gray, supra note 6, at 159-60.

13. As Massachusetts' Reporter of Decisions, Gray had been permitted to practice law. His law office had been attractive to apprentices, affording them the best possible introduction to appellate practice. Gray referred to his protégés as "his boys" and followed their carcers with interest, Gray, supra note 6, at 148, an enthusiasm which apparently he retained as a judge. See S. WILLISTON, supra note 7, at 94.

14. In 1886, Congress began to provide each Justice with a personal assistant. Act of Aug. 4, 1886, ch. 902, 24 Stat. 254.

15. An excellent précis of the evolution of publicly funded law clerks for United States Supreme Court Justices appears in Newland, supra note 1.

The statutory and popular terminology for the assistants to lower court federal judges has always been "law clerk," but new titles have proliferated annong the state courts. See Baier, supra note 1 , at 1130. To conform to the most standard term, and the one predominant in popular usage, this Article will use "law clerk" whenever referring to a law school graduate employed as a legal assistant to a judge. When further specificity is needed, we will follow Professor Meador's distinction between "law clerks" as personal legal assistants provided for individual judges, and "staff attorneys" as legal assistants provided for the collective benefit of a group of judges. D. MEADOR, supra note 1 , at 17.

16. Newland, supra note 1 , at 306.

17. The Act of Mar. 1,1919 , ch. 86,40 Stat. 1264 , provided for nine "stenographic clerks," at a salary of up to $\$ 2,000$ annually. The Act of July 19, 1919, ch. 24, 41 Stat. 209, provided for nine "law clerks," at a salary of up to $\$ 3,600$. As a result of the differing language of these two appropriations, it was unclear whether the higher salaried "law clerks" were to replace the usual "stenographic clerks," or were to supplement them. This was clarified by the language of the Act of May 20,1920 , ch. 214, 41 Stat. 686-87, which provided for nine "law clerks," at an annual salary of $\$ 3,600$, and nine "stenographic clerks," at an annual salary of $\$ 2,000$. See also Newland, supra note 1 , at 302-03.

18. See Newland, supra note 1 , at 303. 
The 1920's and 1930's also saw the use of law clerks spread to lower courts. Congress supplied a clerk to each federal circuit judge in $1930^{19}$ and to selected district judges in 1936. ${ }^{20}$ By 1933, law clerks were employed by the courts of last resort in seven states, ${ }^{21}$ and by 1942, almost half the states provided law clerks for their highest courts. ${ }^{22}$

The postwar decades brought steady growth in the use of law clerks by all courts other than state trial courts. ${ }^{23}$ Since 1970, all United States Supreine Court Justices have had at least three law clerks, ${ }^{24}$ and each federal circuit judge has had at least two. ${ }^{25}$ As of 1965, federal district judges have had the option of having a second law clerk in heu of a court crier. ${ }^{26}$ And since 1973, there have been law clerks at the highest courts of all but six states and at all but three of the intermediate state appellate courts. ${ }^{27}$

A inajor recent innovation in clerkship practices is the use of a

19. Act of June 17,1930 , ch. 509,46 Stat. 774 . Until the 1948 revision of the Judicial Code, Act of June 25,1948 , ch. 646,62 Stat. 920 , the provision of law clerks to circuit judges required the approval of the Attorney General. The curreut provision is 28 U.S.C. $\$ 712$ (1976).

20. The original authorization of law clerks for district judges required a certification of need by the senior circuit judge of the circuit involved, and limited the total number of district court clerks in the first year to 35. Act of Feb. 17, 1936, ch. 75, 49 Stat. 1140. The current provision is 28 U.S.C. $\$ 752$ (1976).

21. California, Illinois, Massachusetts, New Jersey, New York, Oklahoma, and Pennsylvania.

22. ABA Section of Judiclal administration, Methods of Reaching and Preparing Appellate Court Decisions: Report of a Committee to Gather INFormation ConCERning Methods of Reaching and Preparing Appellate Court Decisions 37-38 (1942).

23. See D. MEADOR, supra note 1, at 16; Baier, supra note 1, at 1133-35; P. Barnett, Law Clerks in the United States Courts and State Appellate Courts (Nov. 1973) (Am. Jud. Soc'y Research Study).

24. See H. Abraham, The Judicial Process: An lNtroductory analysis of the Courts of the United States, England and France 239 (3d ed. 1975); G. Casper \& R. Posner, The Workload of the Supreme Court 72 (1976). Mr. Justice Douglas sometimes took one fewer law clerk than authorized. Since 1974, Chief Justice Burger and Mr. Justice White have been experimenting with use of a long-term law clerk in lieu of one of their short-term law clerks. H. ABRAHAM, supra, at 239. The Chief Justice and some associate justices now have four law clerks. See G. CASPER \& R. POSNER, supra, at 109.

25. Professor Carrington, Project Director for the American Bar Foundation, recommended "two, and perhaps three, law clerks" for each circuit judge im his 1968 report. P. Carrington, Accommodating the Workload of the UNited States Courts of Appeals 2 (1968). Since 1974, circuit judges have been able to hire up to three clerks at somewhat reduced rates of pay. As liad been true for many years, each of the acts provided an additional staff salary allowance differential for the chief judge of each circuit and each district court having five or more judges; such chief judges have three law clerks as a matter of course. See also Flanders \& Goldman, Screening Practices and the Use of Para-Judicial Personnel in a U. S. Court of Appeals, A Study in the Fourth Circuit, I JusT. Sys. J. 1, 3, 4 (1975); Wright, supra note 1, at 1179.

26. For a full exphcation of the "convoluted administrative coustraints on the employment of staff by lower federal courts," see J. OAKLEY \& R. THOMPSON, Note on Funding of Law Clerks at Lower Federal Courts, in LAW CleRKS AND THE JudicIal Process app. (1980) (forthcoming) [hereinafter cited as LAW CLERKS].

27. P. Barnett, supra note 23, at 1 . 
"central staff."28 The use of a central staff was first conceived at the Michigan Court of Appeals a decade ago. ${ }^{29}$ Since then the concept of a central staff has becoine the totein of prominent reformers who claim it will save appellate courts from their exploding caseloads and accompanying inefficiency and delay. ${ }^{30}$ Even the inost fervent promoters of the central staff, however, see it as complementary to the personal staff of the individual judge. Its proponents umiversally recommend that although the growth in the numbers of individual law clerks per judge should be limited, such law clerks should not be eliminated. ${ }^{31}$

The central staff explosion over the past decade has been accompanied by the growing use of law students as quasi-clerks to individual judges. $^{32}$ These students, known as "externs,"

28. See generally authorities cited in note 4 supra.

29. See D. MEADOR, supra note 1, at 17. 191.

30. See generally JUSTICE ON APPEAL, supra note 4, at 227-28; D. MEADOR, supra note 1, at

31. See JuStiCE ON APPEAL, supra note 4, at 46, 48; D. MEADOR, supra note 1, at 118. See generally authorities cited in note 1 supra. It is noteworthy that the central staff of the Michigan Court of Appeals, whose effectiveness sparked the inodern spread of the central staff concept, see D. MEADOR, supra note 1 , at 9,17 , was created by pooling a second law clerk which had previously been allocated to each justice. See id. at 9. See generally id. at 198-208; Lesinski \& Stockineyer, supra note 4, at 1213-30. This did not reflect dissatisfaction with the characteristics of individual law clerks of the traditional, newly graduated, short-tern type. As the Chief Judge and the Research Director of that court have written:

In the tradition of law clerkships, the tenure of a prehearing research attorney is generally one to two years. . . .

It was initially envisioned that the prehearing staff would consist largely of career einployees; however, this has not occurred. Indeed, the court is satisfied that the same considerations that have led the overwhelining majority of appellate courts to opt for short-terin law clerks who have recently graduated froin law school apply equally to the prehearing staff. Turnover can intensify administrative problems, but avoids the more subtle adverse effects of institutionalism. Recent law school graduates seem to make up in fresliness of thought and purpose what they may lack in practical experience.

Id. at 1221. Indeed, at the Michigan Court of Appeals the central staff attorneys are recruited froin the same pool as law clerks for individual judges, with the judges given first pick from the short-list of prospects interviewed by a team of one judge and the research director or other senior staff member. Id. at 1220. Staff attorneys and law clerks are paid the same, $i d$. at 1220 n.26, and staff attorneys are occasionally assigned as personal law clerks for temporary judges, id. at 1222 n.28. Such an arrangement for using short-terun staff attorneys cast im the traditional law clerk mold and supervised by a career employee has beeu eudorsed by Judge Leflar. See R. LEFLAR, supra note 1 , at $83-84$. This has been the inodel followed by a number of the federal courts of appeals, including the Ninth Circuit, which announced that effective in the fall of 1977 several additional central staff members, called "court law clerks," would be hired for teruns of one or two years commencing upon graduation froin law school. Court law clerks are hired as JSP-11 employees, and are promoted after one year to JSP-12. Letter from Jolin M. Naff, Jr., Supervising Staff Attorney, United States Court of Appeals for the Ninth Circuit, to "All Placement Directors" (undated, circa summer 1976).

32. See generally Weinstem, Proper and Improper Interactions Between Bench and Law School: Law Student Practice, Law Student Clerkships, and Rules for Admission to the Federal Bar, 50 ST. JohN's L. Rev. 441, 444-50 (1976); Weinstein \& Bonvillian, A Part-Time Clerkship Program in Federal Courts for Law Students, 68 F.R.D. 265 (1975), reprinted sub nom. Law Students as PartTime Court Law Clerks, 15 Judges' J. 58 (1976) (shorteued version). See also Baier \& Lesinski, 
for their judges while carrying a reduced load of law school classes, or are given academic leave from law school for one term to work fulltime. In either case, the student is unpaid but receives academic credit from his or her law school, and thus continues normal progress toward a law degree. ${ }^{34}$ Because no public resources are involved, the use of externs has generally been left to the mitiative of individual judges and law schools. The law schools theinselves have played an active role in the growth of extern programs. ${ }^{35}$

There is a direct relationship between these innovations-the central staff and the extern programs-and the development of a pronounced trend in the state appellate courts of Califorma toward retaining law clerks to individual justices for indefinite periods. This "career clerk" phenomenon has been encouraged both by the legitimation of career employees on central staffs ${ }^{36}$ and by the availability of

In Aid of the Judicial Process: A Proposal for Law Curricular and Student Involvement, 56 JUD. 100 (1972).

33. Although the word has not gained curreucy nationwide, "extern" is the generic term applied to student law clerks throughout California, at both state and federal courts. The etymology of the term has not been documented, but the word appears to lave been coined at the Califorma Supreme Court, circa 1970, as a play on the word "intern." Student law clerks are interns in the conventional sense of unpaid aides rewarded only by experience, yet they are also law students learning law externally from their law schools.

34. See Simonson v. General Motors Corp., 425 F. Supp. 574, 576 (E.D. Pa. 1976); Goodman \& Seaton, The Supreme Court of California, 1972-73-Foreword: Ripe for Decision, Internal Workings and Current Concerns of the California Supreme Court, 62 CALIF. L. REv. 309, 312 n.8 (1974).

At the Supreme Court of California, externs are appointed for the fall semester, the spring semester, or for the summer. Some law schools allow academic credit for a summer extern position, but most do not, out of concern that they may become obligated in fairness to afford academic credit for all manner of other summer clinical activities which could be said to contribute toward a student's legal education. Summer externs at the Supreme Court of California are invariably students between their second and third years of law school. See CAL. CourTs OF APPEAL, supra note 1 , at 81.

35. See Smith v. Pepsico, Inc., 434 F. Supp. 524, 525 (S.D. Fla. 1977); Simonson v. General Motors Corp., 425 F. Supp. at 576; Weinstein \& Bonvillian, supra note 32, at 268.

36. See, e.g., CAL. CourTs of APPEAL, supra note 1, at 88-89. The tendency to view central staff and permanent clerks for individual judges as birds of a feather is appareut in recent coinments of Califorma's chief justice:

At the appellate level, the confluence of two factors - the development of large, impersonal central staffs and the application of a "non-publication" rule-raises some concerns that shonld be addressed.

In Califorma's appellate courts, the recently graduated, one-year law clerk is becoining the exception rather than the rule. The law clerk lias given way to the research attorney whose position is permanent.

The theory underlying this trend is that a professional staff with the continuity of service can develop expertise, thereby saving time in the preparation of cases for the justices' decision. In turn, the justices' time is to be used nore efficiently with the prelimmary work of research and summarization alrcady completed.

Central staff functions may differ somewhat from one appellate court to another, but the potential for mischief in this bureaucratic structure remains the same-the lack of public accountability.

Bird, The Hidden Judiciary, 17 JudGes' J. 4 (1978) (emphasis in original). 
externs to act as surrogates for fresh-faced but inefficient law clerks of the traditional type. ${ }^{37}$ In California, the popularization of experienced central staff attorneys and the pressing need for experience and efficiency produced by the unrelenting increase in the voluune of appellate filings have spurred the hiring of indefinitely tenured law clerks-not as staff attorneys, but as personal assistants to individual judges. ${ }^{38}$ In turn, a sense of the liveliness lost for lack of short-tern clerks and the availability of trusted, experienced assistants to supervise externs may induce an otherwise uninterested judge to participate in an extern prograin. The upshot is that externs tend to becoine the law clerks of the career clerk, dealing with the judge directly on some occasions but receiving unost of their assignments and supervision from the career clerk.

The increasingly pervasive use of career clerks, not as a supplement to traditional law clerks but to their virtual exclusion, is apparently unique to California. Indefinitely tenured law clerks have worked for California's state appellate courts at least simce 1930, and im substantial numbers since 1950. Other jurisdictions, however, have also used such clerks. ${ }^{39}$ Indefinitely tenured assistants were the norm at the United States Supreine Court until Horace Gray's clerkship practices began to prevail im the early decades of this century. ${ }^{40}$ States that provide parajudicial assistance in the form of "commissioners" have historically employed experienced, career-minded attorneys in such posts. $^{41}$

37. In August 1972, the California Supreme Court's 31 research attorneys consisted of 21 permanent employees and 10 temporary employees. As of November 30, 1978, we have ascertained that the court's 33 research attorneys consist of 27 permanent employees and only 6 temporary employees. Interview of Stephen T. Buehl, Executive Assistant to the Chief Justice, Supreme Court of California, im San Francisco, California (Nov. 30, 1978) [heremafter cited as Buehl lnterview]. The percentage of law clerks employed on a short-term basis has thus declined im six years from just over $32 \%$ to just over $22 \%$. During this period, extern use has grown to the point where, by an unwritten and frequently unobserved rule born of a lack of office and library space, each justice is allowed to have "up to three" externs, but no more. See Johnson, The Supreme Court of California 1975-1976-Foreword: The Accidental Decision and How It Happens, 65 CALIF. L. Rev. 231, 249 n.64 (1977). In fact, some justices have had as many as five externs at one time. Thus, use of externs easily has doubled since 1972 . This indicates a positive, inverse correlation between the declining use of short-tern law clerks and the rising use of externs at the California Supreme Court.

38. See CAL. Courts of APPEAL, supra note 1, at 77-78; B. WiTkin, supra note 3, at 12-17.

39. In a survey completed in 1959, out of 44 American appellate courts reporting use of law clerks, six indicated that their clerks served for long periods of time. At 20 of the courts the usual tenure of clerks was one year, and at the rest the period varied from one to three years. Law clerks were exclusively recent law graduates at 24 of the reporting courts, predominately so at 6 more, and about half were recent law graduates at 2 more. At 10 reporting courts, only experienced lawyers were hired as law clerks. ABA SEction of JUdicial ADMINISTRATION, INTERNAL OPERating Procedures of Appellate Courts 45 (1961).

40. See Newland, supra note 1, at 306-08; Williams, supra note 1, at 87.

41. See R. Leflar, supra note 1, at 82-83. See generally Council of STATE Governments, State Court Systems: A Statistical Summary Prepared for the Conference of 
The use of career clerks conflicts profoundly with the model of the traditional law clerk. A central theme of this model is the need for institutional constraimts on law clerks' influence upon judicial decisions. The very shortness of the traditional clerk's tenure prevents him from exerting undue influence. Some judges have never let a law clerk pen a word of opinion; ${ }^{42}$ others have graciously delegated footnotes; ${ }^{43}$ some have made as much use of a law clerk's language as it merits; ${ }^{44}$ and doubtless some have delegated opinion writing to the poimt of dependence. ${ }^{45}$ Yet the central feature of the traditional clerkship is its limited tenure in relation to that of the judge-this is what is thought to keep the roles of clerk and judge in proper perspective. ${ }^{46}$ This perspective is lost, however, with the introduction of career clerkships.

\section{III}

\section{Methodology of THE StUdY}

We set out in this study to observe, record, and report the attitudes and habits of state and federal judges in California who use law clerks to assist them. From the hists of judges appearnig in the California Reports and the Federal Reporter, we identified 105 sittimg judges in California whom we knew to have law clerks. We solicited imterviews with each of these judges. Of the 105 judges contacted, 64 were willing to be interviewed; 63 judges actually were interviewed ${ }^{47}$ between July and

ChIEF Justices 81-84, Table XUI (1974); D. MEADOR, supra note 1, at 14-15, 225-29; NATIONAL Center for State Courts, Parajudges: Their Role in Today's Court Systems 6-7, 30-71 (1976); Curran \& Sunderland, The Organization and Operation of Courts of Review, in Judiclal Council of Michigan, Third Report 65-95 (1933); Spector, Staffs of State Courts of Last Resort (Pt. 1), 34 JUD. 144, 146-48 (1951); Stockmeyer, Borst, Stenger, \& Reid, The Office of the Commissioner of the Michigan Court of Appeals and its Role in the Appellate Process, 48 F.R.D. 355 (1970).

42. See, e.g., Edwards, The Avoidance of Appellate Delay, 52 F.R.D. 61,68 (1971); Medina, The Decisional Process, 20 B. BuLl. 94, 99 (1962) (N.Y. County Lawyers' Ass'n) (describing Judge Learned Hand); W. Leach, Recollections of a Holmes Secretary (Sept. 1940) (unpublished manuscript in Archival Collection, Harvard Law Library).

43. See, e.g., A. Mason, Harlan Fiske Stone: Pillar of the Law 513 (1956); Acheson, Recollections of Service with the Federal Supreme Court, 18 ALA. LAW. 355, 364-65 (1957) (describing Justice Brandeis).

44. See, e.g., J. Frank, Marble Palace 117 (1958); J. Frank, Mr. Justice Black: The Man And His OpINIONs 135-36 (1949); Chilton, Appellate Court Reform: The Premature Scalpel, 48 Cal. ST. B.J. 392, 474 (1973) (California Supreme Court); Cohen, Justice Douglas: $A$ Law Clerk's View, 26 U. CHI. L. Rev. 6, 7 (1958); Meador, Justice Black and His Law Clerks, 15 ALA. L. REv. 57, 60 (1962); Kidney, Anonymous Clerks Serve Justices, Gain Experience, Wash. Post, June 16, 1974, \& L, at 6, col. 1 (Philip Elman re Mr. Justice Frankfurter).

45. See J. Frank, Marble PaLACe 117-18 (1958); Frank, Fred Vinson and the Chief Justiceship, 21 U. CHI. L. Rev. 212, 224, $244-46$ (1954); Roche, The Utopian Pilgrimage of Mr. Justice Murphy, 10 VAND. L. REv. 369, 370-72 (1957).

46. See, e.g. J. WILkINSon, supra note 1, at 59; Chilton, supra note 44, at 466; Newland, supra note 1 , at 316 .

47. We obtained a particularly impressive rate of participation by California appellate 
October of 1976. The average interview lasted over an hour.

We routinely asked permission to speak with the law clerks of the judges to be interviewed. In only one case was permission flatly denied. In inany instances, however, the clerk was unavailable at the conclusion of our interview with the judge, or our schedule precluded interviewing the clerk. We actually interviewed the law clerks of twenty-seven judges. The average interview lasted about half an hour.

The interviews were performed in a rather unsystematic fashion. Many judges are uneasy about discussing their relationships with their law clerks. Our investigative techniques were defined by this atmosphere of privacy. We felt it imperative to adopt an impressionistic research posture to elicit the inaximum number of cooperative responses. Three factors were critical: minimizing deinands on the judge's time, assurmg the judge absolute confidentiality, and remaining sensitive to the unique conditions of each judge's chambers. These considerations all militated against performing a quantitative survey, either by submitting to the judge an attitudinal questionmaire or by requesting oral responses to identical questions dictated from a script.

Our data thus do not purport to be statistically significant or rigorously representative of any class of judges other than the sixty-three individuals we interviewed. We do think that our results have general qualitative validity and that they reflect perceptions of law clerk usage coininonly held by judges nationwide.

Publication of the details of the interviews with individual judges, even without disclosing names, would risk a breach of confidentiahty. Our solution to preserve confidentiality, at some sacrifice in specificity,

judges. As of June 1, 1976, there were 48 sitting justices of the California Courts of Appeal; we were permitted to interview 38 of them, or $79 \%$. In addition, we interviewed five of the seven then sitting justices of the Supreme Court of California, so that overall our subjects included $78 \%$ of the judges then sitting on the appellate courts of California. Two years later our subjects still constituted nearly two-thirds of all California state appellate judges. Included annong the 63 judges whoin we count as having been interviewed are two special cases. One senior federal district judge who authorized his law clerk to answer all our questions was counted as having been interviewed. As a rough device for testing the aceuracy of our interviewing technique, author Thoinpson was hinself interviewed by Oakley on August 6,1976, approximately half-way through the period in which the interviews were conducted. The Thoinpson interview was condueted in the normally formal circumstances of the other interviews, and extended to inany areas of clerkship usage not previously discussed between the authors. The data obtained in that fashion were processed normally and later reviewed in processed form by Thompson, who found thein to present an accurate encapsulation of his clerkship practices and philosophy. Because Thompson was a sitting judge of a California court of appeal and otherwise within the scope of our survey, represented an important minority view among his colleagues regarding proper clerkship usage, and would certainly have consented to an interview of this sort independently of his participation in the underlying study, we decided that our study would be more representative if his interview were included. Durmg the pendency of the interviews, the authors were rarely in contact. At the time he was interviewed, Thoinpson had seen none of the results of the previous interviews, and had discussed the progress of the interviewing schedule in only the inost general terms. 
has been to construct profiles of hypothetical judges whose attitudes and characteristics typify the aggregate of the judges of each court we studied. Our findings are thus presented in the form of composite profiles setting forth the circumstances and behiefs of a "representative" judge of each court. Where significantly different views are held by other judges of a court, these too are presented.

\section{IV}

\section{Profiles of Courts ANd Composite Judges}

\section{A. Courts of Appeal of California}

Appeals from the superior court, California's trial court of general jurisdiction, he initially in one of the courts of appeal. ${ }^{48}$ There are five courts of appeal in Califorma-one for each of five districts. ${ }^{49} \mathrm{Al}-$ though the districts vary in size from four judges to twenty, all cases in the California Courts of Appeal are heard by panels of three judges. ${ }^{50}$

Each judge ${ }^{51}$ on the courts of appeal is allotted a single personal law clerk, or "elbow clerk."52 Approximately two-thirds of the judges have filled this position with a permanent enployee. Roughly the same percentage of judges employ externs. The personal staff of the judges is used primcipally for the preparation of calendar memoranda in civil and difficult criminal cases.

Our research shows that the principal function of central staffs is to "screen" appeals, that is, to sift through fully briefed cases in advance of oral argument to see if any are appropriate for some forni of routine disposition. All criminal appeals are initially routed to a central staff attorney for review and analysis. In some districts, civil appeals also are screened. ${ }^{53}$

48. CAL. Const. art. VI, $\S 11$.

49. See generally CAL. Courts of APpeAL, supra note 1, at 25-29. See also Blume, California Courts in Historical Perspective, 22 Hastings L.J. 121, 173-75 (1970).

50. See CAL. Const. art. VI, § 3.

51. Apart from its consistent reference to the "Chief Justice" of the supreme court and the "presiding justice" of each division of the courts of appeal, CAL. ConsT. art VI, §§ 2-3, the California Constitution is utterly inconsistent in its designation of the members of the supreme court and the courts of appeal, sometimes referring to "justices," and sometimes to "judges." The nnytiad California statutes relating to courts and judicial officers are no inore consistent. We will refer to the "chief justice," to a "presiding justice," and, except where the context warrants otherwise, to the "judges" of both courts.

52. Professor Meador attributes to the Federal Judicial Center the coinage of this useful phrase for distinguishing the personal law clerk of an individual judge from staff attorneys working collectively for that judge's court. See D. MEADOR, supra note 1, at 17 n.45.

53. See generally CAL. COURTS OF APPEAL, supra note 1, at 93-107 (descriptions of central staffs in each district); D. MEADOR, supra note 1, at 11-12. 


\section{Composite Proflle: Judge Alpha}

We interviewed thirty-eight judges of the California Courts of Appeal drawn from all districts and every division. Our coinposite, "Judge Alpha," has been on the bench for nearly ten years, most of the time on the court of appeal and the remainder on a trial court. Prior to becoming a judge, he had practiced law for fifteen to twenty years.

Judge Alpha employs a career law clerk. Although he believes that such a law clerk is, on balance, advantageous to him, his selection of a career law clerk resulted more from drift than from conscious decision. The judge originally had short-term law clerks, as was the custom when he joined the court. One of his clerks stayed over for several years, however, and eventually settled into a career at the court. The judge has soine rather vague misgivings about the role of permanent law clerks in the best of all possible judicial worlds, but he is aware that his judicial world puts a premium on productivity. For him, as for most judges of intermediate appellate state courts, the day of the handcrafted opimion is over. He inust strive not for perfection but for the best quahity obtainable without halting the assembly line of appellate justice. The less time he must spend seeking out and traming new law clerks, the nore time he has to exercise control over the quahty of the work product of his chanbers and of the central staff.

One factor that influenced Alpha to give up short-tern clerks is the difficulty of inducing the best recent law graduates to clerk for the courts of appeal. In the past, Judge Alpha's top clerkship candidate has generally opted for a position with another court. Judge Alpha believes that clerkships at his court are less exciting than clerkships elsewhere. His decision to retain his present clerk indefinitely is the result, in part, of his fear that a short-term clerk would be disappoimted with the clerkship.

A declining minority of court of appeal judges continue to use short-term, "rotating" clerks whom they replace every one or two years. These judges include four of the five court of appeal judges who served as law clerks themselves. The judges in this minority, however, do not display dramatically different attitudes toward the demands of their job or the function of clerks than does Judge Alpha. They are somewhat quicker studies than Alpha (at least in Alpha's opimion) and do not find persomiel decisions to be particularly difficult or painful. Were they to find competent short-term clerks difficult to procure, or were they to find, to their surprise, that some of their successful clerks actually would consider accepting the stultifying (in the judges' opmion) work of a career clerk, they imght well retain pernianent clerks too. They recognize the burden of traming new clerks, but consider it the price they inust pay for clerks of the intellectual acumen they demand. Were 
they allowed two clerks, they would either have the clerks serve staggered two-year terms, so that one experienced clerk would always be available to help train the neophyte, or they would hire one clerk annually and retain the other indefinitely. The latter option is the one that Judge Alpha himself would exercise were he given two law clerk positions, which he thinks is the optnnal number for his court.

Judge Alpha is aware of the potential usurpation of judicial functions by both central staff and career clerks. He is firmly convinced that the danger can be exaggerated, and in any event that harm can be averted by a conscientious judge. Judge Alpha is confident that his own performance is not unduly influenced by his staff; he feels that both central staff and elbow clerks are indispensable to the work of the court, but that, in his case at least, they are essentially technicians who implement decisions he makes personally. $\mathrm{He}$ is aware, however, of colleagues on the courts of appeal who abdicate much of their function to their assistants, and he thinks the problem is worse at the Supreine Court of Califorma.

Indeed, a significant number of the judges represented by Judge Alpha feel that the Supreme Court of California frequently gets out of step with the state because of the undue influence of short-term law clerks at that court. This view, ironic in light of the great numerical predominance of career clerks at the California Supreme Court, is indicative of a lack of consensus among judges of the courts of appeal as to whether short-term or long-tern law clerks pose a greater threat of usurpation. Judges who use career law clerks reject any degree of usurpation in their own chambers but recognize the problem in others, including their colleagues using short-term clerks. Judges using shortterm law clerks tend to agree, however, that an important factor which inhibits them from hiring career clerks is the fear that the longer they worked with a clerk, the inore they would come to rely on his or her judgment, and the more they would risk inadvertently crossing the line of undue delegation of their judicial responsibilities.

Apart fron their concerns over the degree of influence exerted by each type of clerk, there is substantial agreement among the judges of the court of appeal, regardless of their personal clerkship practices, on the advantages and shortcomings of career clerks and rotating clerks. Career clerks offer the advantages of practical experience, inaturity, and knowledge of their judges' personal styles. Because they are generally less assertive than short-ternı clerks, however, career clerks may become bored and stale and may fail to provide the intellectual challenge that the judge needs if he is to continue to produce work of high quality. Short-term clerks generally possess higher intellectual capacity and nore aggressively pursue their ideals than do career clerks. As 
recent graduates of law school, they bring fresh approaches to recurrent legal problems.

Whatever their differences in tenure and personality, the law clerks to judges of the courts of appeal are required to possess essentially similar legal skills. Most important are meticulousness and analytical ability; desirable but less important are excellent grammar and a concise and lucid writing style. Felicitous phrasemaking and a talent for persuasive argument count for little in an interinediate court whose opinions are generally not published. ${ }^{54}$ Judge Alpha believes that his law clerk's effective commumication with him, not with posterity, is the ineasure of the clerk's success im analyzing a case. The clerk's first task is to make sure tlie judge understands any coinphications the case may present.

Clerks at the courts of appeal are used principally to review cases set for the next calendar of oral arguments before the court. The Cahfornia Courts of Appeal uniforinly adopt the "liot bencli" approacli to oral arguinent. ${ }^{\text {ss }}$ Sitting in panels of three judges, the courts hear counsel arnied with a calendar memoranduin that fully discusses the case and with varymg degrees of precalendar preparation beyond the meinorandum by each individual judge. One of the three judges will have been assigned the responsibility for the calendar memorandum for each case. If the case lias been selected for routine treatinent, the judge's responsibility is limited to reviewing the calendar memorandum prepared by the central staff. Otlierwise, the judge is responsible for personally preparing the calendar memorandum, with the assistance of his law clerk.

About one-lialf of the calendar memoranda in criminal cases are the product of the central staff. In soine divisions an oral report sometimes substitutes for a written memorandum.

The judges vary in the annount of instruction given to their elbow clerks for preparation of calendar meinoranda. Some judges instruct their clerks to coinpose memoranda reaching particular conclusions or addressing designated issues. Other judges offer little guidance, expecting their clerks to fornulate not only the result in a case, but also the langnage by which that result is to be aimounced.

There is also httle consensus among the judges on the style and contents of calendar meinoranda. Some judges request a memorandum that offers little inore than a summary of facts and contentions checked against the record. Otlers want a meinorandum in the form of

54. See Wold, Going Through the Motions: The Monotony of Appellate Court Decisionmaking, 62 JuD. 58, 63 (1978).

55. See Thompson, supra note 3, at 478. See also Baier, supra note 1, at 1159 n.124, 1160 n.127; Hufstedler, The Appellate Process Inside Out, 50 CAL. ST. B.J. 20, 23 (1975). 
an opinion written in the first-person-plural. The great majority of judges have their calendar nemoranda prepared in a format that allows easy transformation into an opinion.

There is substantial uniformity among the judges, however, in the use of calendar meinoranda. The memoranda are exchanged among meinbers of the three-judge panel that will hear the cases, and generally are discussed at preargument conferences. ${ }^{56}$ In nost cases, the calendar memorandum significantly colors, if it does not directly become, the opinion of the court.

Occasionally, when he has need of some special factual or legal research which his regular law clerk is too busy to perform, Judge Alpha will secure the services of a central staff attorney or writ clerk.

Judge Alpha also inakes fairly regular use of externs through a prograin organized and administered by the presiding justice and a local law school. Alpha is.satisfied with the extern program so long as the net productivity of his chambers is not reduced by it. With infrequent exception, the judge does not deal directly with externs, preferring to have their work coordimated by his law clerk.

Roughly a third of the judges make no use of externs. They believe that externs have little or nothing to contribute to the work of their chambers or that externs are likely to be political in their approach to the law. Roughly another third are active supporters of extern programs, especially those judges who use short-term clerks. They use extern assistance in lieu of an additional law clerk. Like their peers on the federal district court, they generally assign to externs the same sort of duties given their regular clerks.

The remaining third are represented by Judge Alpha; lie enjoys the fresh attitudes of externs and, so long as the program is administered by someone else, externs are welcolne in his chambers.

\section{B. The Supreme Court of California}

The Supreme Court of Califorma is the state's court of last resort. ${ }^{57}$ It is a court of discretionary jurisdiction, except in capital cases. ${ }^{58}$

56. See generally CAL. Courts OF APPEAL, supra note 1, at 119-23; Molinari, The Decisionmaking Conference of the California Court of Appeal, 57 CALIF. L. REv. 606, 610-12 (1969).

57. CAL. Const. art. VI, $\$ 1$.

58. Even in capital cases the supreme court's consideration of the merits of an appeal is discretionary. Prior to 1966, under former art. VI, $\S 4$ of the Califorma Constitution, the supreme court had jurisdiction over direct appeals in several categories of civil cases as well as capital cases. Nonetheless, most such direct appeals were routinely transferred to the courts of appeal. See 1968 Judicial Council OF CALIFORNIA REPORT 62. This power to transfer remains with the supreme court, CAI. CoNST. art. VI, § 12; CAI. R. CT. 20, and was recently exercised to transfer to the courts of appeal all pending direct appeals which were controlled by the imvahidation of $\mathrm{Cali}$ - 
The court carries its burden with the help of a supporting staff outnumbered only by that of the United States Supreine Court. ${ }^{59}$ At the time of our interviews, the court had thirty-three "research attorneys" $m$ its einploy: three serving each of the six associate justices and fourteen serving the chief justice, with one "principal attorney" nominally serving as the senior staff attorney. The chief justice's staff functioned primarily as a de facto central staff for the screening of petitions for hearing in criminal cases and applications for origmal writs of habeas corpus. ${ }^{60}$ This staff received little direct supervision from the chief justice. The staffs of the associate justices perforned analogous functions with regard to civil petitions, but were more closely supervised by the responsible justices. All but one of the judges used externs at the time of this survey, employing thein principally in the screening process.

\section{Composite Profile: Judge Beta}

Judge Beta-the composite judge of the five justices we interviewed-came to the supreme court after about twenty years of private legal practice and fifteen years of judicial service on a superior court and a court of appeal.

Judge Beta used a short-term clerk when he was on the court of appeal, as was the custom when he started there. When he came to the high court, his supreme court colleagues were in the midst of a transition from a predominantly short-term to a predominantly long-ternn staff. He began with one career research attorney and two short-ternn law clerks. He inherited his first career clerk from his predecessor, who had origmally einployed that clerk on a short-term basis and had then agreed to keep the clerk indefinitely. Judge Beta now has two career clerks, ${ }^{61}$ the second being one of his own fonner short-term clerks who, after a few years in practice, indicated an interest in returning to the court for a career. His third clerk remains a short-term clerk whoin he picks annually from over a hundred apphicants. He enjoys the freshness of short-tern clerks, but receives much of this flavor from his ex-

fornia's death penalty in Rockwell v. Superior Court, 18 Cal. 3d 420, 556 P.2d 1101, 134 Cal. Rptr. 650 (1976). See 1978 Judicial Council of CaLifornia Report 65.

59. See note 24 supra.

60. All criminal petitions are reviewed by a pool of seven long-tern clerks, nominally under the supervision of the chief justice, but treated by her functionally as a central staff, with the chief justice's personal needs for legal staff assistance handled by a distinct group of six law clerks. Included within this personal staff are four short-term clerks. The chief justice's total staff numbers fourteen, including the central staff and her executive assistant, but excluding the court's primcipal attorney. Buehl Interview, supra note 37.

61. See Johnson, supra note 37, at 249 n.64. At present, the Chief Justice of California has four short-term clerks and Associate Jnstices Mosk and Tobrimer have one each. The rest of the legal staff of the court are long-term employees. Buehl Interview, supra note 37. 
terns without the attendant burdens of selecting the clerk and helping him to find a subsequent job.

Judge Beta makes no distinctions between short- and long-term law clerks in detailing the quahities most valuable to a judge: enthusiasin, diligence, legal and analytical skill, and the ability to write clearly and easily. For these reasons, he thinks long-term law clerks are preferably people who were introduced to the suprenne court as short-term law clerks, and who were asked to remain at or return to the court. Career clerks of this type, who are characteristic of those at the supreine court, offer Judge Beta the best of both worlds.

Judge Beta makes extensive use of staff assistance in the screening of petitions for hearings, assigning to his clerks much of the initial responsibility for the preparation of "conference memoranda." These memoranda recommend whether the court should exercise its discretion to grant petitions for hearing in cases previously decided by the courts of appeal. ${ }^{62}$ The court holds weekly conferences to consider pending petitions; hence the derivation of the naine of inemoranda pertaining to petitions. ${ }^{63}$ Conference memoranda are generally self-contamed documents reciting the facts of the case and summarizing the decision of the court below.

Judge Beta recognizes that he is ultimately responsible for the preparation of conference inemoranda. He is also aware, however, that workload pressures require substantial delegation of responsibility to his staff. ${ }^{64}$ Only one judge expressed concern about the extent to which caseload pressures compelled reliance upon staff-prepared conference ineinoranda.

Once the supreine court has decided to exercise its jurisdiction in a given case, the case is assigned by the chief justice for precalendar preparation by a particular judge, most often the one who was responsible for the conference inemorandum in that case if that judge has voted to hear the case. The resulting calendar ineinoranduin is prepared and circulated in advance of oral arguinent and generally assumes the form of a proposed opinion of the court.

Most judges rely heavily on their staffs for preparation of calendar

62. Although petitions for learing are the major category of applications for which the court may assert its discretionary jurisdiction, petitions for labeas corpus and other original writs are also reviewed im conference memoranda and voted upon at the judges' weekly conferences.

63. The California Supreme Court's internal procedures concerning conference and calendar meinoranda are discussed in particular detail in chapter five of LAW CLERKs, supra note 26.

64. The number of petitions for hearings and origimal writs filed with the California Supreme Court increased 358\% from 1957 to 1977 . See id. The burden of processing these petitions is compounded considerably by the court's tacit practice of reviewing cases for mere error, even when such error has no institutional significance beyond lardship to the affected party. See Note on the Supreme Court of California's Exercise of Discretionary Appellate Jurisdiction, id. 
memoranda, but beyond this we could not assemble a useful composite supreme court judge with regard to the writing of opinions. Work habits were too diverse, and even the attitudes of particular judges defy generalization. Individual judges assign varymg roles to their staffs from research and rough drafting to final composition. The degree to which a proposed opinion incorporates material from the underlying calendar memorandum varies not only from judge to judge but also from case to case. The single composite that emerges is that of a judge who is committed to the proposition that by whomever selected and arranged, the words of the opinion must reflect the judge's personal thought process.

Judge Beta does not believe that the supporting staff of the supreme court unduly imtrudes upon judicial decisionmaking. He views the career staff as experienced, skilled technicians able to subordinate personal views to the beliefs of the judge. His staff of two career clerks and a recently graduated short-term clerk plus externs represents, $\mathrm{m}$ his mind, the best possible mix to achieve the advantages of efficiency and cxperience tempered by a fresh dose of ideas einanating from law schools.

A strong advocate of externships, Judge Beta usually has three externs on his staff. ${ }^{65} \mathrm{He}$ finds they provide substantial assistance in the review of petitions mvoking the court's discretionary jurisdiction, a task demanding considerable energy and dedication but requiring less sophisticated skills than the drafting of calendar memoranda or opinions. Externs also bring to the judge's chambers the fresh perspective on legal thinking that he sometinues misses in his predominantly long-term personal staff. They do not detract from the efficient operation of his chambers, however, because they are managed principally by his career clerks. Indeed, Judge Beta's externs function in some ways as the law clerks' law clerks.

Judge Beta, with some dissent from his colleagues, views the operation and impact of the staff at the Califorma Courts of Appeal differently from that of his own court, although the supreme court's review of criminal petitions is functionally similar to the screenimg process of the central staffs of the courts of appeal. He is concerned that career researchers may exercise too much influence over the judges. In particular, he worries that the courts' central staffs signiflcantly reduce judicial control over decisionmaking. Some of his colleagues suspect that the central staffs at the courts of appeal are largely autonomous and concerned primarily with quantitative output. In a similar vein, Judge Beta is concerned that career law clerks at the courts of appeal may be

65. See note 37 supra. 
too influential; nonetheless, Judge Beta admits that he, too, would have a permanent clerk were he still on the court of appeal.

\section{United States Court of Appeals for the Ninth Circuit}

The United States Court of Appeals for the Ninth Circuit hears appeals and petitions for original writs concerning cases from the fifteen federal district courts within the circuit. Litigants are entitled by statute to appeal as of right from all "final decisions" of the district courts not appealable directly to the United States Supreme Court; in some cases, interlocutory decisions of the district courts are also appealable. ${ }^{66}$

At the time of our interviews, the chief judge of the Ninth Circuit had three elbow clerks, and the other judges two each. ${ }^{67}$ The court is a recent convert to the use of central staff, having grown from ten to twenty attorneys in 1976, and currently standing at thirty attorneys with no further growth anticipated in the near future. ${ }^{68}$ The court is experimenting with two innovations in the use of central staff. First, most staff attorneys have been hired on the same recently graduated, short-term basis as traditional law clerks, ${ }^{69}$ under the Nimth Circuit's "court law clerk" progrann. ${ }^{70}$ Second, to facilitate communication with the central staff and maintain the norale of its inembers, the program provides for central staff attorneys to be periodically rotated out to the chambers of cooperating judges for periods aggregating up to one month per year. ${ }^{71}$

The central staff screens all cases coming to the court. It assigns degrees of difficulty to the cases which are used to select those for which waiver of oral argument will be solicited, to group cases for oral argument, and to assign opinions. Members of the staff prepare precalendar bench memoranda in cases of lesser difficulty, and inventory

66. 28 U.S.C. $\S \S 1291-1292$ (1976).

67. See note 25 supra. Although most Nimth Circuit judges with two law clerks desired a third, see note 83 infra, none was inclined to fit a third law clerk within his staff salary limitation by offering all three clerks reduced salaries. The fiscal 1980 appropriations act, passed as this Article was in press, has increased staff salary allowances to the point that all circuit judges may now hire three law clerks at standard salaries. See Act of Sept. 24, 1979, Pub. L. No. 96-68, § 400, 93 Stat. 428.

68. Infornation as to current central staff size and procedures was obtained in an interview with Arthur D. Hellman, Supervising Staff Attorney, United States Court of Appeals for the Ninth Circuit, in San Francisco, California, Apr. 5, 1979.

69. See Federal Judicial Center, Central Legal Staffs in the United States COURTS OF APPEALS 29 (1978).

70. See JustiCe ON APPEAL, supra note 4, at 46, 48; D. MEADOR, supra note 1, at 118.

71. This feature of the court law clerk program was described to us in our interviews. It appears that judges are using staff attorneys as elbow clerks principally in connection with cases for which staff attorneys prepared precalendar bench memoranda. See Federal Judicial CENTER, supra note 69, at 31 . 
the issues presented in cases awaiting oral argument. The central staff also prepares inotion calendars and pro se matters for judicial review and decision. ${ }^{72}$

\section{Composite Profile: Judge Gamma}

Judge Gamma-the composite of six Nimth Circuit judges maintaining chambers in California-came to the bench between ten and fifteen years ago. Prior to becoining a judge, he spent approximately twenty years im private law practice and a few years as a government attorney.

Judge Gamma views the highest function of his personal law clerks as participation in the dialectic resolution of difficult legal issues, which often call for sensitive policy determinations as well as technical virtuosity. He values vigorous presentation by the clerk of an independent position by which he can assess the merit of his own views, and feels this honing clash of ideas could not be duplicated were he dealing with a career retainer. Indeed, he is even reluctant to give way to the incipient trend among court of appeals judges to retaim their clerks for two years each, with staggered ternus so that there is always a semor and a junior clerk in chambers. He recognizes clear advantages to productivity through such a system, but has been worried that a clerk will become stale during the second year, and that the best clerkship prospects will be deterred by a two-year requirement. The success of his colleagues in obtaining superior law clerks even for two-year terins and his contimued receipt of a hundred or more applications from highly qualified clerkship candidates each year are about to prompt him, too, to shift to a two-year system, but he has a nagging concern that even this nodest departure front the traditional clerkship is a subtle coinpromise forced upon him by rising caseloads.

Judge Gamma frequently uses his law clerks to assist in reviewimg opimions circulated by the other judges on his panel. A few of his colleagues find, however, that caseload pressures generally preclude the use of clerks for such matters. There is even more variation among Nimth Circuit judges in the use of law clerks for precalendar preparation. Two judges regarded the preparation of bench memoranda as too time-consuining for their law clerks, who are unfamilar with this aspect of a judge's work, and therefore perforined that task themselves with some help from externs.

Judge Gamma personally crafts his opimions to ensure that they are the product of his own reasoning. With relatively few exceptions he uses his clerks' draft opimions as working papers, rewriting the drafts

72. See generally Hufstedler, supra note 55, at 21-22. 
almost entirely. A mmority of Judge Gamma's colleagues are more willing than he to incorporate substantial portions of law clerks' drafts into their opinions. They have fewer fears than Gamma of falling unduly under the analytical influence of their clerks.

In hiring his personal law clerks, Judge Gamma looks for a complex mix of talents and emotions: legal brilliance, assertiveness, diligence, exceptional writimg ability, technical skill, meticulousness, creativity, "jurisprudential imagmation," and common sense. He is convinced that he is much inore likely to find those qualities in a shortterm, newly graduated clerk than in a career court-employed lawyer, and that the new graduate will therefore be a markedly superior participant in the dialectic process of decisionmaking than his career counterpart.

Judge Gamma confesses candidly to a fear that if he employed career researchers as his elbow staff, he too would becoine overly dependent on the product of a trusted coworker, and in turn the career researcher would tend too mucli to try to reacli results that he believed most acceptable to the judge-at the expense of the value of a decision achieved through argument and counterargument. He accordingly regards it as virtually inconceivable that the Nimth Circuit will ever come to einploy career research attorneys as personal law clerks. He is already concerned-indeed, one of his colleagues expressed "shock"-at the extent of the influence of the senior career clerks at the California Supreme Court, as perceived im that court's opinions and corroborated by his law clerks' peers at that court.

Although he feels vague qualms about its impersonality, Judge Gamma accepts the mstitution of central staff and his court's growing use of it as indispensable to preservation of his ability to handcraft the law in the face of the "crisis of volume." He is not overly concerned about undue influence accruing to the career lawyers of the Ninth Circuit's own central staff, partly because of the limited role to which the court has consciously confined them. He has soine worry that, after a period of four or five years of employment, the career staff attorneys may become overly bureaucratized. This concern leaves him somewhat torn in his attitude towards the low pay of the court's permanent staff attorneys, ${ }^{73}$ while low pay ineans that the court cannot attract ca-

73. The 12 permanent staff attomeys at the Ninth Circuit are not nearly as highly paid as those of the Califorma state appellate courts. The principal attorneys of the courts of appeal receive up to $\$ 43,884$ per year. The 33 most senior law clerks at the courts of appeal (excluding primcipal attorneys) receive up to $\$ 36,972$ per year. See 1978-79 California Governor's Budget REPORT, SALARIES AND WAGES SUPPLEMENT 2-3. In contrast, the chief staff attorney for the entire circuit was limited by statute to no more than $\$ 34,000$ in fiscal 1978. The remaining staff attorneys were limited to no more than the JSP equivalent to GS 12 , which was $\$ 28,444$-at its highest step in fiscal 1978. See Exec. Order No. 12,010, 42 Fed. Reg. 52,365 (1977), reprinted 
reer employees of the caliber of the best senior research attorneys at the Supreme Court of California, it also encourages a high degree of turnover among the permanent staff, thereby mitigatimg the danger of bureaucratization, excessive influence, and gradual judicial dependence.

Judge Gamma believes he could put one more law clerk to good use, and looks forward to being able to employ a third clerk. In the meantimie, he generally has an extern on hand. One judge opposes externs on grounds of principle, believing that the government ought not to accept free services and that externs threaten the confidentiality of the court. Other judges habitually have two and sometimes three externs assisting them. Given their mtimate relationship with their law clerks, Nimth Circuit judges tend to employ externs only imsofar as the externs contribute to their chambers' productivity; their varymg views on that score account chiefly for their varying use of externs. Active extern users generally have imstitutional ties with particular law schools that supply externs, and sometimes clerks as well, on a regular basis.

\section{United States District Courts of California}

The district court is the trial court of general jurisdiction in the federal system. There are four United States district courts im Califorma, rangimg im size from seventeen judges in the Central District (in Los Angeles) to six judges in the Eastern District (im Sacramento). The other districts are based in San Francisco and San Diego. ${ }^{74}$

The district judges supervise the trial of facts before juries and act as finders of fact themselves in certain cases. They also decide numerous questions of law upon motions to dismiss or for summary judgment.

District judges have at least one law clerk; most employ two. No district courts have central staffs, as such, although some districts with substantial prisoners' rights litigation have employed "writ clerks" or "pro se" clerks since the mid-1960's. ${ }^{75}$ These law clerks are not neces-

following 5 U.S.C.A. $\$ 5332$ (West Supp. 1978). Since our interviews, two JSP-14 and three JSP13 positions have been provided on the Ninth Circuit's central staff. See [1977] REPORTS OF THE Proceedings of the Judiclal Conference of the UNITEd States 56. These positions carty fiscal 1978 salary ranges of $\$ 30,750$ to $\$ 39,975$ and $\$ 26,022$ to $\$ 33,825$, respectively, under Exec. Order No. 12,010, supra. These positions presumably will be salaried at the lower salary steps within the JSP-13 and JSP-14 grades, since the posts are described as assistants to the senior staff attorney, whose salary in fiscal 1978 was limited by statute to $\$ 34,000$.

74. The size of the California districts is prescribed by Act of Oct. 20, 1978, Pub. L. No. $95-$ 486, § 1, 92 Stat. 1629 (amending 28 U.S.C. $\S 133$ (1976)); their geographies are prescribed by 28 U.S.C. $\$ 84$ (1976).

75. See Zeigler \& Hernann, The Invisible Litigant: An Inside View of Pro Se Actions in the Federal Courts, 47 N.Y.U.L. REv. 157, 176 (1972). The larger California districts similarly en1ploy "writ clerks." 
sarily hired on a short-term basis, but generally remain with the court for a limited period. An increasing amount of legal assistance-in some ways the functional equivalent of the work of central staffs-is being provided to district courts by federal magistrates. ${ }^{76}$

\section{Composite Profile: Judge Delta}

Judge Delta-the composite of fourteen federal district judges we interviewed from the four California districts- has been a district judge in regular, active service for about ten years. He came to the bench after fifteen to twenty years of extensive litigation experience. Several of his colleagues came to the district court by way of the California trial court bench.

Since taking the bench, Judge Delta has become firmly convinced that no experience can better prepare a law student for a life practicing law than a clerkship at a federal court - a district court for the litigation-oriented, a circuit court of appeals for the more academically inclined. He regards law review experience as an essential qualification. It is the best guarantee, in his view, that a clerk will possess the qualities most important for the job: initiative, writing skills, and the ability to respond positively and productively to time pressures.

The judge began his career on the federal bench by employing a "court crier," or bailiff, 77 and a single law clerk. He inherited the bailiff from his predecessor at the district court and agreed to retain the bailiff until the latter's retirement. Although he developed a great affection for his bailiff, Judge Delta quickly realized that he would benefit nore froin the services of a second law clerk. He thus encouraged his bailiff to retire early and hired a second law clerk as a replacement. ${ }^{78}$

For some time, Judge Delta functioned with two clerks selected

76. See generally $\mathrm{S}$. Flanders, District Court Studies Project INTERIM RePort 60-62 (Federal Judicial Center, June 1976); Kaufman, The Judicial Crisis, Court Delay and the Parajudge, 54 Jud. 145 (1970); Zeigler \& Hermann, supra note 75, at 208 \& n.219. See also 28 U.S.C. $\$ \S 631-639$ (1976).

77. Although officially classified as a court crier, 28 U.S.C. $\$ 755$ (1976), most judges referred to such a person as a "bailiff." Accord, S. FLANDERS, supra note 76, at 62.

78. An additional law clerk hired in lieu of a court crier or bailiff is officially classified as a "crier-clerk." See LAW CleRKS, supra note 26. By a nearly incomprehensible system of staff salary limitations, district judges are given a choice of sorts between hiring two law clerks or a law clerk and a bailiff. See id.

Five of our 14 subjects still had court criers instead of a second law clerk, but each indicated that he would hire a second law clerk upon the retirement of his crier. None of our subjects indicated that fewer than two clerks would be optimal.

At the time of our study, only chief judges of districts with five or more judges were entitled to hire a third law clerk, see note 25 supra, and indeed $75 \%$ of our subjects felt that two rather than three clerks was optimal, doubting their ability effectively to supervise more than two clerks at a time. The courtroom obligations of district judges severely limit their ability to monitor and coordinate the hour-by-hour activities of their clerks in chambers. 
annually. He hesitated requiring two-year clerkships out of fear that the longer terin would be unfair to the clerks and discourage the best applicants. The judge recently overcame these qualms, however, and began to hire clerks for two-year staggered terins, with one new clerk arriving each year. His burden of selection has been cut in half as a result, and he now always has one experienced clerk on hand to keep the work flowing as the new clerk learns the job. ${ }^{79}$ Notwithstanding an madequate first-year salary and the two-year commitment, the quahty and quantity of clerkship apphicants has not suffered from his new clerkship pohicy.

Judge Delta uses his law clerks im a variety of ways, but their primary tasks arise in connection with substantive inotions. The judge has a weekly motion calendar, which sometimes may consume an entire court day. Civil and criminal motions are generally heard on alternating weeks. The clerks divide pending motions among themselves and review each, researching selected points very briefly. Generally, Judge Delta requests a single precalendar memorandum that collects and describes the pending motions, noting troublesome issues in highly summary fashion; usually no more than a paragraph is devoted to each case. Most of the procedural motions are decided from the bench, as are some of the more substantive ones. Motions taken under submission are researched in accordance with the judge's instructions; since Judge Delta makes it his practice to decide submitted cases by written opinion, the postcalendar research memoranda of his clerks are usually prepared as draft opinions.

Within the parameters of Judge Delta's motion practice there are inany individual variations by his colleagues. One judge generally reviews pending motions himself, preferring to save his clerks' time for substantive motions filtered out by the judge and assigned for special precalendar treatment, or for the drafting of opinions on motions taken under submission. Another judge encourages oral reports on pending motions when other duties prevent extensive law clerk precalendar preparation. Judges vary greatly in the frequency with which they decide inotions by written opimions and in the frequency with which they subınit their opinions for publication in the official reports; these variations affect their clerks' postcalendar activities. ${ }^{80}$

79. All five of our subjects with only one clerk hired that clerk annually, but six of the nine subjects with two clerks hired their clerks for two-year staggered terms. Of the three subjects with two annual clerks, two inade it their practice to have one new clerk arrive a inonth or so earlier than the other, to allow some overlap between the outgoing and incoining clerks. The third judge accomplished the same objective by attempting to have both new clerks arrive several days before the departure of his old clerks.

80. Judge Delta's clerks operate in conventional Ninth Circuit fashion when Judge Delta sits by assigninent on the court of appeals. They prepare precalendar inemoranda to Delta's specifica- 
The judge recently has had one or two externs working in his chambers. He has mixed feelings about externs, believing on balance that they contribute marginally to his chamber's productivity. Some of Judge Delta's colleagues believe that externs are a burden on the court. Others think that externs are more than marginally helpful. At times, Judge Delta has been on the verge of dropping his extern program, but positive contributions by particularly adept externs have caused him each time to change his mind. He reduces tlie administrative burden of the extern program by leaving the selection process to one or more cooperating law schools, and interposing his law clerks as the externs' first level of supervision.

Delta's clerks perform a host of other chores ancillary to the trial of cases. They advise the judge on jury imstructions and procedural rulings. They also draft memoranda of decisions as outlined by the judge in cases in which he is the trier of fact. The mechanical aspects of operating the courtroom are handled by the judge himself, however, together with the deputy clerk and reporter assigned to Judge Delta's courtroom. The judge rarely requires his law clerks to be in the courtroom, but he encourages their attendance when time permits.

Judge Delta frequently engages, at his own imitiative, im discussion of problem cases with his clerks. He believes that such dialectic argument contributes substantially to the sharpening of his own thought processes and to the quality of his decisions. He considers it the job of his law clerks to prevent him from making mistakes. It is inconceivable to him that the district court could operate effectively without these clerks; in a word, they are "indispensable."

He recognizes that his law clerks have considerable influence on his ideas and on the content of his opimons; indeed, he treasures the articulate clerk who can write well. However, he does not fear ideological influence by his clerks; the mistakes they correct are misperceptions of law, not misconceptions of policy. A talented clerk is a valuable tool for cominunicating the ideas and decisions of the judge who is informed but not inveigled by the dialectic with his clerks. Occasionally, that dialectic leaves the judge and a clerk in irreconcilable positions; if this prevents the clerk from adequately drafting an opimion, the judge is quite prepared to produce the opimion on his own.

Judge Delta finds the prospect of having a permanent clerk unpalatable. He can conceive of a proper role for such clerks at appellate courts, in conjunction with continued use of short-term clerks. Nonetheless, were he to hire a permanent clerk he would be nagged by fears

tions; these memoranda are much more detailed than those relating to pending trial motions. After oral argument at the court of appeals, Judge Delta's clerks prepare draft opinions in the cases assigned to him. 
of encroachment upon his autonomy. He would appreciate being reheved of the considerable burden of selecting his short-term clerks, but his recent adoption of two-year, staggered terms for his clerks has already reduced this burden somewhat. To the extent trial judges need long-term assistants with special expertise, Judge Delta prefers expanding the role of magistrates to employmg career clerks or central staffs.

\section{CONCLUSION}

Judges of the four courts we studied generally agreed about the advantages of short-term clerks. When their qualitative preferences are not overridden by other concerns, judges favor the short-term law clerk whom the mantle of tradition marks as a messenger from academia, whose vision of the court is fresher, whose criticism is less subdued, and whose zest for the dialectic process of justifying a proposed judicial decision is greater than that of the career clerk.

Nonetheless, particularly in state courts, judges tend to hire longterm clerks despite voiced misgivings about their effect on the judicial process. ${ }^{81}$ Our study leads us to conclude that the chief factor in the decline of the traditional clerkship at the four courts we studied is overly burdensome caseloads. As this pressure mounts, and with it the workload per clerk, judges place a premium on clerks who require less training and have sufficient experience to work efficiently without direct supervision. The timie spent im clerk selection becoines a luxury, especially at courts of lesser prestige, ${ }^{82}$ where the quality of applicants may make the search not worth the effort. Thus, for administrative rather than intellectual reasons, the career clerk appeals to the harried judge.

81. Most judges recognized that substitution of career staff for traditional clerks poses a risk of undue delegation of judicial prerogatives to staff, although none perceived the risk as a reality in his own operation. Some who did not perceive the personal risk, however, had adopted a method of operation by which their first impression of a proposed decision was imposed upon a career staff attorney, who was expected and conditioned to accept it without question and forthwith to articulate reasons for the conclusion. Such judges failed to recognize that such a process removes from appellate decisionmaking the traditional discipline of personal efforts at articulation of reasons for a decision-efforts that test the validity of first impressions as to the proper outcome of cases.

82. Judges of the federal courts and the Supreme Court of Cahfornia had many highly qualified applicants for clerkship openimgs. The attractiveness of federal district courts varies somewhat with locale, but the nationwide uniformity of federal practice and the interest of law students in trial litigation stimulates national interest in clerkships at California federal district courts. The Supreme Court of California has long been a coveted clerkship opportunity. The Ninth Circuit offers the prominence of a high court and the familiarity of federal practice, and it has frequently served as a steppingstone to clerkships at the United States Supreme Court.

In contrast, judges of the California Courts of Appeal have difficulty competing for the best clerkship candidates. 
To the extent that they act as research assistants rather than parajudges, law clerks are limited in their ability to reduce caseload pressures. Clerks can draft working opinions and evaluate briefs or pleadings, but because their recommendations are subject to review by the judge, the usefulness of additional law clerks will be determined by the ability of a court to supervise thein. At the trial level, inuch of a judge's work is beyond the ken of law clerks. At the appellate level, law clerks are likely to be inore pervasively useful, since all cases require careful legal analysis preliminary to the exercise of judicial discretion. Thus, as appellate caseloads rise, it follows that the workload of appellate court law clerks also rises. In such a situation, judges who feel they lack a sufficient number of law clerks ${ }^{83}$ inust deinand productivity above all else-forcing them to choose experienced law clerks who can work swiftly and with minimal supervision.

Use of short-tern clerks at the California Supreme Court is inhibited by the magnitude of caseload pressures and the felt obligation to scrutinize the discretionary docket with elaborate care. ${ }^{84}$ The judges do not believe additional law clerks would do much to lessen the court's burden in reviewing discretionary petitions, not because the clerks would be unable to perform the tasks, but because the judges believe they could not control nuore than three personal clerks effectively.

The extremity of the workload per clerk at the California Supreine Court, notwithstanding the lack of desire for additional law clerks, is demonstrated by the rise in extern use which has accompanied the decline there, since our interviews, in the use of short-term clerks. ${ }^{85}$ Since externs are managed by the court's career law clerks, thereby relieving the judge of supervisory responsibility, externs can increase the productivity of a judge's staff.

Moreover, at the California Supreme Court the screening function perfornied elsewhere by discrete central staffs is perfornied by the personal staffs of the judges. This places a premium on the experience of the long-term clerk who can sort the routine from the unusual with

83. There was great disparity in the satisfaction of our subject judges with the numbers of law clerks provided them for personal use. Seventy-five perceut of responding federal district judges were happy with their curreut complement of two clerks; twenty-five percent would have preferred a third. All responding Cahfornia Suprcine Court judges were content with their current complement of three personal clerks. Sixty-oue percent of responding California Courts of Appeal judges were dissatisfied with their allotment of one elbow clerk; eighty perceut of responding Ninth Circuit judges also wanted an additional elbow clerk. On the basis of workload per law clerk, theu, only the judges of the two intermediate appellate courts in our study beheved that there was inore work suitable for law clerks to do than there were law clerks available to perform such work. As this Article went to press, Ninth Circuit judges had just obtained funding for a third law clerk each. See note 67 supra.

84. See note 64 supra.

85. See note 37 supra. 
dispatch and without the continual supervision a series of short-term clerks would require. Supreme court judges rely heavily on the judgment of their clerks and the court would be severely hainpered if matters pending at weekly conferences had to be postponed frequently for reexamimation of the recommendations im conference memoranda. This puts a gloss on the ineaning of "productivity" that short-term clerks are hard put to fulfill.

The caliber of long-term clerks at the Cahfornia Supreme Court virtually equals that of the traditional short-terni clerk. Indeed, most of the court's career clerks were once short-terni clerks. The court's prestige and its high salaries ${ }^{86}$ liave enabled it to attract excellent lawyers to its pernianent staff. In these circumstances, the judges' relatively weak predisposition for traditional clerks on qualitative grounds pales beside the demand for staff productivity.

The judges of the California Courts of Appeal generally feel that they are underequipped with personal clerks, and that they therefore must emphasize quantitative output in choosing the one clerk each is allowed. The judges do recognize qualitative distinctions between the career clerks and short-terni clerks employed at the court, but the majority feel compelled by the need for efficiency to rely on a career clerk so long as they are limited to one personal clerk per judge.

Federal judges have generally been allowed to hire clerks in sufficient numbers to avoid judicial overemphasis on law clerk productivity in a quantitative sense. And the prestige of the federal courts has attracted candidates of outstanding ability who consequently may require less training and direct supervision by the judge. The productivity of federal court law clerks has been further enhanced througlı staggered, two-year clerkships that have reduced the administrative burdens associated witlı short-tern 1 law clerks without decreasing the quality of clerkship applicants.

Productivity is of less concern to federal district judges, who treat their clerks as confidants as well as research assistants. Similarly, Ninth Circuit judges reserve elbow clerks for cases in which the judges feel the need for extensive research and discussion. Routme inatters are handled by a central staff that has recently grown to substantial size. This suggests that, were caseloads to rise significantiy in the future, the court may be receptive to the employment of career clerks.

86. The salary of the highest paid law clerk in the state, the Principal Attorney of the Supreine Court of California, is $\$ 46,044$ for fiscal 1978. The ten most senior law clerks at the supreme court (excluding the principal attorney) receive up to $\$ 41,844$ per year. See $1978-79$ California Governor's Budget Report, Salaries and Wages Supplement 2-3. To compare the salaries of perinanent staff attorneys at the California Courts of Appeal and the Ninth Circuit, see note 73 supra. 
Whatever their individual practices, most judges we interviewed beheve that short-term clerks are qualitatively superior to career clerks. Although soine judges have retained a coterie of exceptional career clerks, who bring to the court many of the valued qualities of shorttern clerks without the attendant administrative burdens and who can more efficiently manage the court's discretionary docket, inost judges would prefer a traditional clerk if their working conditions permitted it. We have identified, therefore, a number of ways to foster the use of short-terin clerks at state and federal courts. We believe these measures can reconcile the conflicting desires of judges to enjoy the qualitative benefits of working with traditional law clerks without wholly sacrificing the efficiencies of the new trends in judicial staff assistance.

At the California Supreme Court, for example, short-term clerks could be more effectively employed if the petitions for discretionary review were centralized. Drawing from the experience at the Ninth Circuit, the present de facto central staff for criminal petitions should be expanded to include initial processing of all petitions for discretionary review. The personal staffs of the mdividual supreme court justices could continue to assist the judges in reviewing conference memoranda. As at the Ninth Circuit, the primrary function of the judges' personal staff should be to prepare the judges for oral argument, and to aid the judges in airing their views through their written opinions. Released froin the primcipal responsibility for screening petitions for discretionary review, a short-term clerk in each chamber could be einployed in the manner of the traditional clerk. The judges themselves believe, however, that there is a limit to the number of shortternı clerks they could successfully employ. If the traditional clerkship is to benefit both the judge and the clerk, that number should not be exceeded.

While some advocate a system of "flexible funding" 87 to foster the use of short-term clerks at California's courts of appeal, we believe an aggressive approach would be more effective. The pilot project recently begun by the Judicial Council of California at the urging of Chief Justice Bird, by which selected judges of the courts of appeal are

87. The systein is, in effect, a hybrid of the federal and state models of law clerk funding. It would afford courts of appeal judges a pot of money as in the federal system, but allow them to hire highly experienced career clerks at competitive salaries if they wished to expend their budget on one experienced career clerk instead of two short-term, newly graduated clerks. Although judges expressed support for such a system, they were also concerned about its associated administrative burdens. Moreover, given the courts' extreme caseload and low prestige among clerkship apphicants, this systein might not prove efficacious. Further, such a budgetary proposal would be impractical to effectuate, given California's current budgetary procedures, which are keyed to the authorization of particular employee positions rather than to the authorization of a set amount of funds for a variable number of employees. 
afforded an additional law clerk budgeted at a short-term, newly graduated salary level, should be expanded to include every judge of the courts of appeal. In this way, those judges who expressed a desire to hire an additional law clerk could do so without being forced to choose between retaining a single career clerk or a short-term clerk. Permittimg each judge of the courts of appeal to employ an indefinitely tenured clerk as well as one clerk for only one year allows for flexibility im clerkship policies. Those judges who feel most pressed by the burdens of law clerk selection and training can employ a career clerk to do this administrative work. Other judges, especially those presently using short-term clerks, may wish to adopt the staggered, two-year clerkship policy which has proved highly successful in the federal courts. In this way judges could opt either for a short-termed staff with their administrative burdens mitigated by staggered two-year terms, or for the administrative advantages of a permanent clerk assisted by a short-term clerk replaced annually.

We hope that the addition of a short-term clerk would, despite the need for training and supervision, help to reduce caseload pressures sufficiently to allow the blossoming of the interaction which typifies the traditional relationship between the judge and the short-term clerk.

The difficulties of courts of appeal judges in attracting clerks of the highest caliber might decrease were it to become known to better qualified candidates that the courts of appeal were committed to a policy of providimg each judge with an additional clerk for an annual term. Indeed, these courts might prove especially attractive to the occasional outstanding clerkship candidate who wishes to spend just one year in this type of training, and who might have to remain for two years as a condition of a federal court clerkship.

We disagree with the California Judicial Council's pilot project, however, insofar as it uses additional short-term law clerks as substitutes for central staff. While our research has not been directed to the proper organization and supervision of central staffs, we repeat here our advocacy of the Ninth Circuit's inodel for preserving traditional judge-law clerk relationships by diverting routine inatters to central staffs. Whether, given their standing, the central staffs of the courts of appeal can attract short-tern law clerks of the Ninth Circuit's stature is debatable. The Ninth Circuit's ability to maintain substantial control over the work of the central staff through meaningful review by individual judges assisted by their law clerks has, however, been established. The Ninth Circuit's central staff procedures should therefore be followed by the Califorma Courts of Appeal, even if career staff attorneys are employed. Increasingly, the law clerks of courts of appeal judges will allow those judges more systenatically to review the work 
product of their courts' central staffs, and to improve the quality of their relationships with their elbow staff.

We expect career clerks to become more common in courts outside California. We suspect, however, that the California Supreme Court and Courts of Appeal have passed the poimt at which the quantitative benefits of career clerks are offset by qualitative costs. California's experience may be imstructive. As courts imcreasingly resort to career clerks to remedy congested dockets, we urge that the qualitative differences between long-term and short-term clerks be minimized by recruitimg long-term clerks from a court's short-term alumm.

Finally, we suggest that no matter how satisfied a court is with its complement of career clerks, it never permit its judges completely to insulate themselves from short-tern1 clerks. There is a need for shortterm clerks at the elbows of our judges, respecting the traditions of their place, knowing who they are and what the law expects them to do: to prod their judges, to expand their judges' awareness, to test their judges' conclusions, to color their judges' thinking and embellish their judges' writing, and then to go their separate ways. 